\title{
Introduction
}

HENRIK HORN

PETROS C. MAVROIDIS

\section{The project}

This is the third volume of the Reporters' Studies undertaken in the context of the American Law Institute (ALI) project Principles of World Trade Law: The World Trade Organization (WTO). The aim of the project is to provide a systematic analysis of WTO law based in both Economics and Law. This year's focus has mainly been on disputes that came to an administrative end during the year 2003, either because they were not appealed or because the appeal process concluded. Each dispute has been evaluated jointly by an economist and a lawyer. The general task of this two-person team is to evaluate whether the ruling "makes sense" from an economic as well as a legal point of view and, if it does not, whether the problem lies in the legal text or in the interpretation thereof. The authors do not always cover all issues discussed in a case, but they seek to discuss both the procedural and the substantive issues that form the "core" of the dispute, as they see it.

The Reporters' Studies have, this year, been drafted by the following persons, who have been appointed Reporters for the project by the ALI:

Gene M. Grossman, Jacob Viner Professor of International Economics, Princeton University, USA.

Henrik Horn, Professor of International Economics, Institute for International Economic Studies, Stockholm University, Sweden. Robert L. Howse, Alene and Allan F. Smith Professor of Law, University of Michigan Law School, USA. 
Petros C. Mavroidis, Professor of Law, University of Neuchâtel, Switzerland, and Edwin B. Parker Professor of Law at Columbia Law School, USA.

Damien J. Neven, Professor of Economics, Graduate Institute for International Studies, University of Geneva, Switzerland.

Robert W. Staiger, Professor of Economics, University of Wisconsin, USA. Alan O. Sykes, Frank and Bernice Greenberg Professor of Law, University of Chicago Law School, USA.

Joseph H.H. Weiler, Joseph Straus Professor of Law and Jean Monnet Chair, New York University School of Law, USA.

The Reporters' Studies were initially scrutinized in an October 2004 meeting of all of the Reporters in Princeton. After revisions, the Studies were presented and discussed in a meeting held in Geneva on April 12, 2005, with the following group of lawyers and economists:

Richard Baldwin, Graduate Institute of International Studies, Geneva, Switzerland.

Armin von Bogdandy, Max Planck Institut, Heidelberg, Germany. Claus-Dieter Ehlermann, Wilmer Cutler, Brussels, Belgium.

Wilfred J. Ethier, Department of Economics, University of Pennsylvania, Philadelphia, USA.

Gary Horlick, Wilmer Cutler, Washington DC, USA.

Gabrielle Marceau, World Trade Organization, Geneva, Switzerland. Mitsuo Matshushita, Seikei University School of Law, Tokyo, Japan. Niall Meagher, Advisory Centre for WTO law, Geneva, Switzerland. Håkan Nordström, National Board of Trade, Stockholm, Sweden. Donald Regan, University of Michigan School of Law, Ann Arbor, USA. Delissa Ridgway, US Court of International Trade, New York, USA. Frieder Roessler, Advisory Centre for WTO law, Geneva, Switzerland. André Sapir, Université Libre de Bruxelles, Brussels, Belgium. Arun Venkataraman, World Trade Organization, Geneva, Switzerland. Jasper Wauters, World Trade Organization, Geneva, Switzerland. Eric White, EC Commission, Brussels, Belgium. Claire Wright, Thomas Jefferson School of Law, San Diego, USA. Werner Zdouc, World Trade Organization, Geneva, Switzerland.

The final versions, as published in this volume, have been subjected to yet another round of revisions derived from the advisory meeting. Despite these collective efforts, each pair of authors remains solely responsible for the Studies it has authored. 
This project would not have existed had it not been for the efforts and commitment of Professor Lance Liebman, Director of the ALI. We have also benefited greatly from the support of the President of the ALI, Michael Traynor, the ALI Deputy Director, Elena Cappella, and the former ALI Deputy Director, Michael Greenwald. The ALI has also provided excellent assistance with the administration of our meetings. We are extremely grateful for the generous financial support the project has received from Jan Wallander's and Tom Hedelius' Research Foundation, Svenska Handelsbanken, Stockholm, and the Milton and Miriam Handel Foundation. Without their support, this project would not have materialized.

\section{The Reporters' Studies on the WTO Case Law of 2003}

We here provide a brief summary of this year's Studies in the order of their appearance in this volume.

A main theme in this year's Studies has been contingent protection. Grossman and Sykes discuss the compliance dispute between India and the European Community (EC) in which India alleged lack of compliance by the EC with an earlier WTO ruling on antidumping duties for cotton-type bed linen. India raised issues relating to the EC treatment of "other factors," that is, issues regarding the manner in which an investigating authority should treat factors, other than those mentioned in the body of the Agreement, that cause injury. India had briefly noted such factors in the original proceedings but had not argued them fully. Although, in their view, Grossman and Sykes can imagine cases where the failure by a panel to investigate factual aspects of a case might in and of itself warrant a reversal of its eventual finding, they decline to pronounce on the existence of such grounds in this dispute, lacking an effective demonstration by India that the Panel's omission led to abuse or a biased outcome. The authors go one step further, however, and suggest that this issue raises interesting questions regarding the proper scope of res judicata, issue preclusion, and waiver in WTO jurisprudence. To highlight these questions, they develop an analytical model to compare expected litigation costs in a judicial system with a rule of waiver to those in a system in which litigants can bring multiple claims. They show that a rule of waiver need not minimize litigation costs, because some disputes can be resolved at lower costs if a claimant is not forced to bring all of its arguments at once. India also claimed that the EC violated WTO rules when 
conducting its revised injury analysis, by treating all imports from firms not individually investigated as if they had been dumping, despite the fact that some of the firms individually investigated were found not to be dumping. On this score, the authors conclude that the Appellate Body's $(\mathrm{AB})$ decision has some economic appeal, but rests on shaky legal foundations.

In their paper on Corrosion Steel, Howse and Staiger deal with the legal benchmark to be applied by an investigating authority when evaluating whether to retain antidumping duties beyond the original five-year period (the sunset review). The current law is quite openended and requires WTO Members to demonstrate the likelihood of continued or renewed dumping before agreeing on the extension of duties in place. In the authors' view, a meaningful assessment of the likelihood of continued or renewed dumping requires an understanding of the conditions that led to dumping in the first place, and a determination of whether these conditions have changed in a way that removes the original reason for dumping. In their opinion, neither of these two elements appears to have played any real role in the US investigating authority's methodology for determining likelihood, or in the AB's assessment of the legitimacy of this methodology. The authors note that Art. 9.1 of the Antidumping Agreement (AD) does not require an assessment of the conditions that have led the companies named in an antidumping order to dump; the authors maintain, however, that a different criterion should be applied in Art. 9.1 AD compared to that applied in Art. 11.3 AD. They see no necessary inconsistency in this: while a requirement could have been included in the $\mathrm{AD}$ that the particular reasons for dumping must be articulated as a condition for imposing antidumping duties under Art. 9.1 AD, there is no logical necessity that such a requirement must be included. By contrast, Howse and Staiger argue that an understanding and articulation of the conditions that led to dumping is logically necessary to assess the likelihood of continued or renewed dumping, and therefore, is an implied condition for extending definitive antidumping duties beyond the five-year termination date that Art. 11.3 $\mathrm{AD}$ otherwise dictates. In light of their preferred benchmark for the adjudicating of such cases, the authors conclude that the $A B$ erred by not requiring the United States to provide such an assessment as part of its sunset review.

The "Byrd" litigation between the United States and a number of WTO Members over the US Continued Dumping and Subsidy Offset Act 
of 2000 (CDSOA) is discussed by Horn and Mavroidis. This United States law reserves disbursement of collected antidumping and countervailing duties exclusively to those economic operators that have backed a petition to open a dumping (or countervailing) investigation. The $A B$, in part modifying the Panel's findings, concluded that the law was WTO-inconsistent in that it constituted an impermissible action against dumping (and subsidization). In the authors' view, the $\mathrm{AB}$ erred both in terms of its reasoning and in terms of its findings: the AB's treatment of the reasons advanced by the Panel to support its finding that the Byrd legislation violated Art. 18.1 AD and Art 32.1 of the Agreement on Subsidies and Countervailing Measures (SCM) was inconsistent; the $\mathrm{AB}$, in striking down the legislation, used an economic theory that was inadequately motivated and of doubtful validity, if meant to describe the legislation's typical impact on various industries, and it failed to explain how general it believed the theory to be; the $\mathrm{AB}$ struck down the legislation on much weaker grounds than those it had previously established as a requirement in its case law; and finally, the $\mathrm{AB}$ should have undertaken a more comprehensive discussion of the claims under Art. 5.4 AD and 11.4 SCM, since an illegality could more naturally have been established under these provisions.

Horn and Mavroidis also discuss the Pipe Fittings litigation between Brazil and the EC. In this dispute, Brazil raised a series of issues concerning the lawfulness of the EC imposition of antidumping duties against imports of pipe fittings originating in Brazil. Chief among the issues raised were questions relating to the treatment of a devalued currency, the conditions under which low-volume imports should be considered imports in the ordinary course of trade, and the scope of information that should go into a final notice advising interested parties as to the extent of an antidumping imposition. In the authors' view, the AB's conclusions with respect to the first two issues are hardly supported by a contextual understanding of the various obligations laid down in the AD. Disregarding the implication of a devaluation (and its effect on pricing decisions) would lead the investigating authorities to practice antidumping against its very purpose: antidumping measures are not available to provide injured parties with a lump-sum payment, but, instead, to offset dumping occurring in future transactions (i.e. after the conclusion of the investigation). Additionally, the $\mathrm{AB}$ 's understanding of the discretion conferred upon the investigating authorities when constructing the normal value would lead, as it did in the present case, to logically incoherent outcomes. Finally, the authors 
argue that the transparency obligations should be read in light of their purpose, which is to inform uninformed parties the basis of decisions made during the investigation and thus to ensure that due process has been adhered to throughout the whole administrative procedure, otherwise these obligations will be reduced to mere procedural requirements that do not perform their assigned function.

The Softwood Lumber IV litigation between Canada and the United States is also examined by Horn and Mavroidis. This dispute is part of the long-standing conflict between Canada and the United States concerning the forestry sector. A main issue in the present dispute concerns the benchmark that a WTO Member can use in order to calculate the amount of subsidization. In this dispute, the Panel concluded that there was a problem with the current text of the SCM Agreement in that it does not include sufficient flexibility to allow WTO Members to use alternative benchmarks when confronting a factual situation not envisaged by the law itself; accordingly, the Panel indirectly argued for some form of legislative amendment. The $\mathrm{AB}$ did not agree with the Panel's reading, however, concluding that the existing text reflects sufficient flexibility to allow WTO Members to deal with situations such as the one in the present dispute. The authors, however, find it hard to interpret Art. 14(d) SCM so as to allow for alternative benchmarks, such as the benchmark proposed by the United States. In their view, the $A B$ here effectively took on the role of legislator, thus contravening the discipline laid down in Art. 3.2 of the Understanding on Dispute Settlement.

Grossman and Sykes discuss the steel disputes between the United States and a host of complainants that challenged the consistency of safeguards in the steel sector imposed by the United States against imports from a variety of sources. The authors take the position that the AB's decision in this dispute is one more link in a line of unsatisfactory decisions in the safeguards area. In their view, the underlying problem stems from the fact that the treaty text regarding the preconditions for the use of safeguard measures is seriously deficient. The $\mathrm{AB}$, with its usual emphasis on textual interpretation, has done little to resolve the puzzles that the text creates. As a result, WTO members are still left with little guidance concerning the proper use of safeguards beyond some confusing and sometimes incoherent standards, notwithstanding the sizeable amount of jurisprudence in this field. The authors review these issues as they have arisen, not only in the instant decision, but in prior decisions as well, and then discuss the details of the steel 
dispute. They place more emphasis on the Panel report than the $A B$ report, as the latter breaks little new ground. In the authors' opinion, although it is probably difficult to quarrel with the outcome in this particular case (in light of the procedural deficiencies they observe), it is high time to reverse the tide in the safeguards area by breaking with the current line of jurisprudence.

Some of the reports discussed in this year's volume deal with issues other than contingent protection. Neven and Mavroidis discuss the first "genuine" services litigation in the WTO context, the dispute between the United States and Mexico concerning the rates charged by the Mexican monopolist, Telmex, for terminating calls originating in the United States (Mexico - Telecoms). The Panel, whose findings were never appealed, found that Telmex was charging rates unrelated to its cost structure, thus violating its obligations under the General Agreement of Trade in Services (GATS). The authors critically distance themselves from both the Panel's reasoning and its findings: in the authors' opinion, the Panel mischaracterized the facts before it, and, moreover, applied the wrong law. In their view, Mexico had made no commitment regarding the factual situation as presented by the complaining party (and was hence not bound by the relevant legal framework). Furthermore, even if it had made such commitments, the relevant framework did not address the situation before the Panel (cross-border supply of termination services), but rather addressed only the mode- 3 supply of telecoms services (commercial presence of the supplier in the market of the country terminating incoming calls). The authors conclude that the Panel's findings constitute an impermissible extension of the existing legal framework to transactions that the founding fathers did not intend to cover. They also take a critical stance with respect to the pure competition-law component of the dispute, where they argue that it was an overly bold move for the Panel to pronounce on whether the rates charged were cost-oriented, in light of the information presented before it. The Panel's approach is, from the authors' perspective, at odds with the approaches of numerous competition authorities on the same score.

Grossman and Sykes deal with the Generalized System of Preferences (GSP) dispute between India and the EC, where, for the first time, the legality of practices by donor countries under the terms of the Enabling Clause was being discussed. In this case, India complained against the EC practice of making distinctions among developing countries, and, based on such distinctions, granting additional 
preferences to some developing countries (those that had engaged in combating drug production and trafficking). The $\mathrm{AB}$, overturning in part the Panel findings in this respect, condemned the specific EC practice (because the list of beneficiaries was closed), but accepted the principle that the making of distinctions among developing countries was perfectly compatible with the WTO legal order, to the extent that objective criteria had been established ex ante. The authors disagree with both the reasoning and the outcome of this litigation. In their view, the EC scheme could, at least theoretically, lead to trade diversion, with less efficient developing countries increasing their exports at the expense of the exports of more efficient developing countries. Moreover, in the authors' opinion, beyond the original distinction between developing and least developed countries that is enshrined in the WTO legal framework, and the graduation from developing to developed country status, there is no justification for schemes such as the one contested in this case. Finally, from a policy perspective, there is no reason to believe that such schemes are to the benefit of the countries receiving preferences.

Howse and Staiger discuss the arbitration on the 1916 Antidumping Act, which addresses the meaning of equivalence between a violation of international law and the countermeasures applied to respond to the violation. In this case, the EC proposed countermeasures that "mirrored" the US WTO-inconsistent behavior (the availability of a private right of action for treble damages against a foreign firm engaging in certain kinds of dumping). Based largely on previous rulings, the Arbitrator held that, while the central purpose of countermeasures under DSU Art. 22 was to induce compliance and exclude punitive purposes, it could not endorse the proposed countermeasures of the EC, unless it had evidence that the trade or economic effect of the EC mirror-reaction on the United States would not exceed the trade or economic effect of the United States' original action on the EC. The authors reject the Arbitrator's approach for several reasons: first, in their view, the Arbitrator focused on the word "level" without also considering its immediate context-the notion of "equivalence." The word "equivalence" implies proportionality between two things that are not entirely commensurate or reducible in value to a common metric. Second, "normative countermeasures," where equivalence or proportionality is achieved by suspending a symmetrical obligation, have often been recognized as consistent with the principles of state responsibility. Third, the Arbitrator confused the issue of the limits 
on countermeasures with the issue of whether the purpose of countermeasures was to re-establish the pre-breach equilibrium between the parties, to achieve compliance, or to punish. The authors also advance in their paper some normative thoughts on the placement of efficient breach of contract inside the current WTO legal regime. They argue that the Arbitrator's focus on trade effects has some merit from an economic point of view, and they also propose how the trade foregone should be measured.

Neven and Weiler review the decision by the AB in the Japan Apples dispute, which concerns measures affecting the importation of apples in Japan. The authors emphasize that a crucial aspect of the Sanitary and Phytosanitary (SPS) agreement is that it imposes a discipline on risk-reducing measures even in the absence of discrimination in favor of domestic products. Their discussion on the evaluation of risk-reducing measures focuses on two issues, namely the scope of the mandate given to the adjudicators and the standard of review that they should apply. Neven and Weiler emphasize the difficulty that adjudicators face in distinguishing between the level of risk that a country will find it optimal to support (which cannot be challenged), and the question of whether the risk-reducing measures are necessary to achieve the chosen level of risk. They further observe that the common methodology used by panels, evaluating the existence of risk in the absence of risk-reducing measures, has limited applicability. The authors also discuss how the Panel's approach can be abused, leading the adjudicators to slip from the evaluation of whether a measure is necessary to achieve a given level of risk to an implicit challenge of the level of risk itself (which should remain the preserve of the Members). Regarding the standard of review, they argue that a lower standard should be applied to measures that do not threaten fundamental principles like nondiscrimination. Finally, the authors also consider the Precautionary Principle in the context of the SPS Agreement. In their view, the provisions of the SPS Agreement reflect the distinction between risk and ambiguity: whereas the former would cover the provisions that concern science-based SPS measures, the latter would extend to cover precautionary measures. The authors consequently call into question the Panel's and the AB's unwillingness to apply the Precautionary Principle in the context of this dispute.

This year, we will not attempt to classify the papers according to whether the authors see the rationale provided by the adjudicating bodies, or the outcome, as correct. Nevertheless, we observe that, 
in basically all the disputes discussed, the authors raise serious concerns about the adjudicators' reasoning in support of the final outcome. Whether the outcomes of the disputes make sense from an economic point of view is more difficult to judge this year, since the Studies to a large extent address antidumping issues, and, as is well known, it is difficult to reconcile antidumping measures with standard economic reasoning. 